\title{
The use of lipoprotein apheresis for the treatment of high-risk patients with elevated lipoprotein(a) and hypercholesterolemia
}

\author{
Michael Yaroustovsky, Marina Abramyan, Ekaterina Rogalskaya, Ekaterina Komardina \\ Federal State Budget Institution «A.N.Bakulev National Medical Research Centre for Cardiovascular Surgery» of the Ministry of \\ Healthcare of the Russian Federation (Bakulev NMRCCS), Moscow 121552, Russia.
}

Correspondence to: Prof. Michael Yaroustovsky, Burakovsky Institute for cardiac surgery, Department of Detoxication and Endoscopy Bakulev National Medical Research Centre for Cardiovascular Surgery, Rublevskoe highway 135, Moscow 121552, Russia.E-mail: mbyar@yandex.ru

How to cite this article: Yaroustovsky M, Abramyan M, Rogalskaya E, Komardina E. The use of lipoprotein apheresis for the treatment of high-risk patients with elevated lipoprotein(a) and hypercholesterolemia. Vessel P/us 2019;3:9. http://dx.doi.org/10.20517/2574-1209.2019.02

Received: 10 Dec 2018 First Decision: 20 Jan 2019 Revised: 21 Jan 2019 Accepted: 22 Jan 2019 Published: 22 Mar 2019

Science Editor: Alexander N. Orekhov Copy Editor: Cai-Hong Wang Production Editor: Huan-Liang Wu

\begin{abstract}
Aim: To assess the safety and efficiency of H.E.L.P.-apheresis and cascade lipid-filtration in the treatment of severe lipid disorders in high-risk patients.

Methods: From 2016 to 2018 we observed 6 patients hyperLDLemia and high Lp(a)emia (> $60 \mathrm{mg} / \mathrm{dL}$ ). The first group with H.E.L.P.-apheresis ( $n=74$ sessions) included 3 patients who underwent revascularization (coronary, femoral arteries). In the second group with cascade lipid-filtration ( $n=92$ sessions) - one patients underwent revascularization, two patients received drug therapy. Despite the lipid-lowering conventional therapy, no targeted low density lipoprotein (LDL) was obtained.
\end{abstract}

Results: The patients of the 1st group had threefold decrease of LDL, in patients of the 2nd group LDL decreased by $68 \%$. At the same time, in both groups, we noted a decrease in $L p(a)$ after the procedure by 65\%-68\%. Despite a decrease in high density lipoprotein (by 22\%-29\%) after lipid apheresis procedures, there was a positive trend in apoB100/apoA index (a decrease of 33\% after HELP-apheresis procedures and 60\% after cascade lipid-filtration) and a decrease in atherogenic index (38\% and 53\%, respectively). The changes in hematological and haemostatic parameters remained within physiological intervals.

Conclusion: We noticed the successful application of lipid apheresis in patients with multifocal atherosclerosis and its complications.

CC (i) (c) The Author(s) 2019. Open Access This article is licensed under a Creative Commons Attribution 4.0 International License (https://creativecommons.org/licenses/by/4.0/), which permits unrestricted use, sharing, adaptation, distribution and reproduction in any medium or format, for any purpose, even commercially, as long as you give appropriate credit to the original author(s) and the source, provide a link to the Creative Commons license, and indicate if changes were made. 
Keywords: Lipid disorders, hyperLDLemia, high Lp(a)emia, multifocal atherosclerosis and its complications, atherogenic index, H.E.L.P.-apheresis, cascade lipid-filtration

\section{INTRODUCTION}

Despite the progress in diagnostics and therapy of cardiovascular diseases, atherosclerosis and related events (myocardial infarction, stroke, and peripheral vessels damage) are still the leading causes of morbidity and mortality. As assessed by World Health Organization, cardiovascular mortality ranges from $48 \%$ to $56 \%$ all over the world ${ }^{[1,2]}$.

The pathogenesis of atherosclerosis includes disorders of lipid and carbohydrate metabolism, hemostasis and immune systems. Dyslipidemia (mainly presented as hypercholesterolemia type IIa and IIb) is the risk factor of atherosclerosis and related events ${ }^{[3-6]}$. The process of atherosclerosis can be triggered even in childhood and can evolve throughout life. It is so important to timely evaluate the existing hemostatic disorders, screen risk factors, make the right choice of the treatment, and take early preventive measures ${ }^{[7]}$.

Treatment of lipid metabolism disorders mainly involves conventional tactics (diet, statins, fibrates, cholesterol absorption inhibitors and, etc.). In most cases hyperlipidemia can be quite adequately corrected with the conventional therapy. It is known that statins had beneficial effects on cardiovascular pathology and mortality. However, there are some cases noted for lack of efficiency and resistance to lipid-lowering therapy (monotherapy or combination with medications of multiple effects), intolerance to the pharmacological therapy and development of side effects.

On the other hand, there are combinations of different types of dyslipidemia [hyperLDLemia, hyperLp(a) emia]. Low density lipoprotein (LDL) is well-established risk factor for atherosclerosis that can be treated by lipid-lowering drugs. Lipoprotein(a) $[\mathrm{Lp}(\mathrm{a})]$ is independent risk factor for atherosclerotic cardiovascular diseases, that cannot be corrected by dietary changes or medication ${ }^{[8]}$. Lp(a) occurs in isolation or in combination with other types of dyslipidemia, that increases atherogenic properties of them ${ }^{[9-12]}$. In such cases extracorporeal therapy is an additional and/or alternative approach with proved efficiency. In nowadays apheresis techniques are used for patients with incurable dislipidemia, hyperLp(a)emia, hyperviscosity syndrome with high fibrinogenemia, high risk of cardiovascular events with damaged vessels ${ }^{[13-16]}$. An alternative therapeutic option of hypercholesterolemia can be plasmapheresis.

The first extracorporeal treatment of hypercholesterolemia was performed in 1967 by plasma exchange in patients with familial hypercholesterolemia ${ }^{[17]}$. In the late ' 70 s - early ' 80 s in Great Britain, Thompson (1980) managed to reach regression of coronary artery atherosclerosis when lipids' level was lowered aggressively by plasmapheresis $^{[18,19]}$.

Since then methods, equipment and understanding of extracorporeal therapy have changed significantly. Our goal is to eliminate a large amount of atherogenic substances from the circulation and to change the ratio of lipid in the direction of antiatherogenic. After all, the removal of atherogenic lipids in a large amount (up to $60 \%-80 \%$ per one session) can create conditions for the "release" of cholesterol from plaques. This can be considered as one of the specific mechanisms of influence on the development of atherosclerosis ${ }^{[20,21]}$. This problem is managed by lipoprotein apheresis ${ }^{[22-24]}$.

Current lipoprotein apheresis methods are based on different technologies (filtration, adsorption, precipitation), and their main aim is to remove atherogenic lipoproteins from the circulation ${ }^{[14,25-27]}$. They are cascade lipid-filtration, heparin-extracorporeal LDL-precipitation, direct adsorption of lipoprotein, 
immunoadsorption of lipoproteins, dextran sulfate adsorption, and all these procedures alter the physicochemical and biochemical properties of lipoproteins.

Greater efficiency and selectivity have been gained with the implementation of new synthetic membranes for rheofilters [Cascadeflow-EC50, Lipidfilter EC-50, Evaflux 4A, 5A (Japan)] in the treatment of lipid metabolism disorders. This type of blood purification procedures was named cascade lipid-filtration ${ }^{[28]}$. Klingel et al. ${ }^{[28]}$ (2004) observed the decrease of total cholesterol, LDL, Lp(a) and fibrinogen after treatment of more than $3300 \mathrm{~mL}$ plasma; no significant changes of levels of high density lipoprotein (HDL), proteins, immunoglobulin were detected, so it is a safe and effective method.

Another LDL-apheresis method based on the precipitation of atherogenic lipids in the acid buffer and with high doses of heparin is called H.E.L.P.-apheresis (Heparin-induced extracorporeal LDL-precipitation). This method aimed at lipids reduction and correction of rheological parameters, hemostasis, immunological homeostasis $)^{[29,30]}$.

The aim of this study is to evaluate safety and efficiency of H.E.L.P.-apheresis and cascade lipid-filtration in the treatment with severe disorder of lipid metabolism in high-risk patients.

\section{METHODS}

From 2016 to 2018 we observed 6 patients with multifocal atherosclerosis before and after sessions of myocardial revascularization, arteries of lower limbs (CABG, angioplasty and stenting). The study was approved by the Local Ethical Committee of the Center. Patients included in the study signed an informed consent for extracorporeal therapy. Patients were chosen by the decision of doctors' consilium (cardiologists, cardiac surgeons, specialists of blood purification).

The patients had severe dyslipidemia (type IIa), heart and vessels diseases. All the patients showed hyperLDLemia combined with high Lp(a)emia (> $60 \mathrm{mg} / \mathrm{dL}$ ), and the level of $\mathrm{Lp}(\mathrm{a})$ of 5 patients was higher than $90 \mathrm{mg} / \mathrm{dL}$. The conventional therapy included antiplatelet medications (Clopidogrel, acetylsalicylic acid), lipid-lowering drugs (statins, Ezetrol), if necessary according to the indications - calcium antagonists, ACE/ARA inhibitors, $\beta$-blockers [Tables 1 and 2 ].

The decision to initiate the selective lipid apheresis - treatment was made considering the anamnesis and laboratory data. The first group with H.E.L.P.-apheresis ( $n=74$ sessions) included 3 patients with multifocal atherosclerosis, who had undergone revascularization (coronary arteries, femoral artery) [Table 1]. In the second group with cascade lipid-filtration ( $n=92$ sessions) one patients underwent revascularization surgery, two patients received conventional therapy [Table 2]. Despite the lipid-lowering conventional therapy, no targeted LDL was obtained. Atherogenic indexes remained moderate: in the 1st group on average $3(2.35-4.5)$ and in the second group $3.8(3-6.15)$.

The main effect of H.E.L.P.-apheresis is the elimination of atherogenic lipoproteins due to precipitation. During H.E.L.P.-apheresis, atherogenic lipoproteins and plasma fibrinogen precipitate on-line in the presence of high heparin doses and acetate buffer. Primarily, blood passes through the plasma filter (surface area 0.3-0.5 $\mathrm{m}^{2}$, rate $60-80 \mathrm{~mL} / \mathrm{min}$ ). Red blood cells are returned to the patient, and plasma is mixed with acetate buffer $(\mathrm{pH}=4.85)$ in the ratio $1: 1$ and with heparin solution $(100 \mathrm{U} / \mathrm{mL})$. This acidic mixture $(\mathrm{pH}=5.12)$ reaches the precipitating filter with the rate $20-30 \mathrm{~mL} / \mathrm{min}(25 \%-30 \%$ of blood flow) and precipitates there with further deposition of insoluble sediments of LDL, Lp(a), triglycerides and fibrinogen. Heparin excess is eliminated from plasma on heparin adsorber (DEAE of cellulose). Bicarbonate dialysis is used for restoration of plasma $\mathrm{pH}$. After that plasma is returned to the patient in combination with red blood cells. If necessary, 
Table 1. Clinical characteristics of patients before H.E.L.P.-apheresis therapy

\begin{tabular}{|c|c|c|c|c|c|}
\hline Patients & $\begin{array}{l}\text { The disorders of lipid metabolism } \\
\text { (with drug therapy) }\end{array}$ & $\begin{array}{l}\text { The manifestations } \\
\text { of atherosclerosis } \\
\text { (vessels) }\end{array}$ & $\begin{array}{c}\text { Revascularization } \\
\text { procedure }\end{array}$ & Drug therapy & Comorbidity \\
\hline No.1 & $\begin{array}{l}\text { Hypercholesterolemia ( } \mathrm{LDL}>4 \\
\text { mmol/L, atherogenic index }>4 \text { ) } \\
\text { hypertriglyceridemia }(>4 \mathrm{mmol} / \mathrm{L}) \text {, } \\
\text { hyperLp(a)emia }(>60 \mathrm{mg} / \mathrm{dL})\end{array}$ & Coronary & $\begin{array}{l}\text { Coronary artery } \\
\text { stenting }(n=2)\end{array}$ & $\begin{array}{l}\text { Statin (atorvastatin } 10 \text { ) } \\
\text { antiplatelet agents } \\
\text { (clopidogrel, acetylsalicylic } \\
\text { acid), angiotensin receptor } \\
\text { inhibitors, } \beta \text {-blockers, } \\
\text { L-thyroxine }\end{array}$ & $\begin{array}{l}\text { Hypertensive } \\
\text { disease } \\
\text { Type } 1 \text { diabetes, } \\
\text { angiopathy, } \\
\text { retinopathy, } \\
\text { nephropathy. } \\
\text { Hypothyroidism }\end{array}$ \\
\hline No.2 & $\begin{array}{l}\text { Hypercholesterolemia (LDL }>4 \\
\text { mmol/L, atherogenic index }>5.5 \text { ) } \\
\text { hypefibrinogenemia }(>4 \mathrm{~g} / \mathrm{L}) \\
\text { hyperLp(a)emia (> } 200 \mathrm{mg} / \mathrm{dL})\end{array}$ & $\begin{array}{l}\text { Coronary } \\
\text { Brachiocephalic }\end{array}$ & $\begin{array}{l}\text { Coronary artery } \\
\text { stenting }(n=6)\end{array}$ & $\begin{array}{l}\text { Statin (rosuvastatin 10) } \\
\text { antiplatelet agents } \\
\text { (clopidogrel, acetylsalicylic } \\
\text { acid) } \\
\beta \text {-blockers }\end{array}$ & $\begin{array}{l}\text { Iron deficiency } \\
\text { anemia } \\
\text { Vascular } \\
\text { calcification }\end{array}$ \\
\hline No.3 & $\begin{array}{l}\text { Hypercholesterolemia (LDL }>3.5 \\
\text { mmol/L, atherogenic index }>5.5) \text {, } \\
\text { hypefibrinogenemia }(>4.5 \mathrm{~g} / \mathrm{L}) \text {, } \\
\text { hyperLp(a)emia }(>60 \mathrm{mg} / \mathrm{dL})\end{array}$ & $\begin{array}{l}\text { Coronary } \\
\text { Brachiocephalic } \\
\text { Femoral }\end{array}$ & $\begin{array}{l}\text { 1. Coronary artery } \\
\text { stenting }(n=2) \text {; } \\
\text { 2. Femoral-popliteal } \\
\text { bypass }\end{array}$ & $\begin{array}{l}\text { Statins (rosuvastatin 10), } \\
\text { antiplatelets (aspirin, } \\
\text { xarelto, clopidogrel), ACE } \\
\text { inhibitors, CA antagonists, } \\
\text { cytostatics }\end{array}$ & $\begin{array}{l}\text { Chronic kidney } \\
\text { disease, after renal } \\
\text { transplantation } \\
\text { Hypertensive } \\
\text { disease } \\
\text { Iron deficiency } \\
\text { anemia } \\
\text { Vascular } \\
\text { calcification }\end{array}$ \\
\hline
\end{tabular}

LDL: low density lipoprotein

ultrafiltration can be applied (up to $600 \mathrm{~mL}$ per session). Up to $4000 \mathrm{~mL}$ of plasma can be treated during one session; it corresponds approximately to one plasma volume circulating in an adult. H.E.L.P.-therapy was performed on Plasmat Futura (B|Braun, Germany), which is easy to use and safe to apply. Circuit preparation and reinfusion are automated.

Cascade lipid-filtration is based on the separation (by filtration) on membrane plasma filters with different permeability capacities. It is a consecutive cascade technique affecting specific range of substances with the principle of double-filtration plasmapheresis. First, blood is separated from red blood cells when passing through the plasma filter, and then rheofilter is used for targeted specific elimination of substances. Rheofilters with different permeability are chosen depending on the aim of the treatment. For lipid apheresis techniques, extracorporeal circuit should contain the rheofilter with permeability for substances, whose molecular weight is less than the weight of $\operatorname{IgG}(<150000 \mathrm{D})$. After passing through the rheofilter, plasma filtrate containing IgG, HDL and other substations of plasma with lower weight molecules, is returned to the patient with the red blood cells. High weight molecules (LDL, Lp(a), VLDL, triglycerides, chylomicrons, fibrinogen) remain in the rheofilter. Treated plasma volume was 3,500-4,500 mL per session. Cascade lipidfiltration was performed on Plasauto (Asahi, Japan).

In our study we chose cubital veins as vascular access, and no problems with the satisfactory blood flow were noted. We evaluated the clinical and laboratory indications before and after the session.

Statistical analyses were performed with IBM SPSS statistics for Windows (Mann-Whitney $U$ test, $P$ values less than 0.05). The data are expressed as the median and 25th-75th percentiles.

\section{RESULTS}

We performed 166 sessions of H.E.L.P.-apheresis and cascade lipid-filtration for 6 patients with cardiovascular diseases. The procedure frequency was once per 3-4 weeks. No side effects were detected in the patients during the study (allergic reactions, bleeding, etc.). No circuit thrombosis was observed. The interviewed patients observed significant improvement of the clinical state. New acute cardiovascular events 
Table 2. Clinical characteristics of patients before lipid-filtration therapy

\begin{tabular}{|c|c|c|c|c|c|}
\hline Patients & $\begin{array}{l}\text { The disorders of Ipid } \\
\text { metabolism } \\
\text { (with drug therapy) }\end{array}$ & $\begin{array}{c}\text { The manifestations } \\
\text { of atherosclerosis } \\
\text { (vessels) }\end{array}$ & $\begin{array}{l}\text { Revascularization } \\
\text { procedure }\end{array}$ & Drug therapy & Comorbidity \\
\hline No.1 & $\begin{array}{l}\text { Hypercholesterolemia } \\
(\mathrm{LDL}>4.5 \mathrm{mmol} / \mathrm{L} \text {, } \\
\text { atherogenic index } \\
>4.5) \\
\text { hypefibrinogenemia } \\
(>4 \mathrm{~g} / \mathrm{L}) \\
\text { hyperLp(a)emia } \\
(>150 \mathrm{mg} / \mathrm{dL})\end{array}$ & $\begin{array}{l}\text { Coronary } \\
\text { Brachiocephalic } \\
\text { Femoral }\end{array}$ & $\begin{array}{l}\text { Coronary artery bypass } \\
\text { graft }(n=3) \text {, Mitral valve } \\
\text { repair with Carpentier } \\
\text { techniques }\end{array}$ & $\begin{array}{l}\text { Statin (rosuvastatin 20), Ezetrol } \\
\text { antiplatelet agents (clopidogrel, } \\
\text { acetylsalicylic acid) } \\
\text { ACE inhibitors } \\
\beta \text {-blockers } \\
\text { Calcium antagonists }\end{array}$ & $\begin{array}{l}\text { Hypertensive } \\
\text { disease } \\
\text { Hyperuricemia }\end{array}$ \\
\hline No.2 & $\begin{array}{l}\text { Hypercholesterolemia } \\
(\mathrm{LDL}>6.5 \mathrm{mmol} / \mathrm{L}, \\
\text { atherogenic index }>7) \\
\text { hypefibrinogenemia } \\
(>4 \mathrm{~g} / \mathrm{L}) \\
\text { hyperLp(a)emia } \\
(>60 \mathrm{mg} / \mathrm{dL})\end{array}$ & $\begin{array}{l}\text { Coronary } \\
\text { Brachiocephalic }\end{array}$ & No & $\begin{array}{l}\text { Statin (rosuvastatin 40), } \\
\text { Ezetrol antiplatelet agents } \\
\text { (acetylsalicylic acid) } \\
\beta \text {-blockers }\end{array}$ & $\begin{array}{l}\text { Left ventricular } \\
\text { aneurysm } \\
\text { Hyperuricemia }\end{array}$ \\
\hline No.3 & $\begin{array}{l}\text { Hypercholesterolemia } \\
(\mathrm{LDL}>4 \mathrm{mmol} / \mathrm{L}, \\
\text { atherogenic index }>3) \\
\text { hypefibrinogenemia } \\
(>4 \mathrm{~g} / \mathrm{L}) \\
\text { hyperLp(a)emia } \\
(>300 \mathrm{mg} / \mathrm{dL})\end{array}$ & Brachiocephalic & No & $\begin{array}{l}\text { Statin (rosuvastatin 40) } \\
\text { antiplatelet agents } \\
\text { (acetylsalicylic acid) }\end{array}$ & $\begin{array}{l}\text { Iron deficiency } \\
\text { anemia } \\
\text { Vascular } \\
\text { calcification }\end{array}$ \\
\hline
\end{tabular}

LDL: low density lipoprotein; ACE: angiotensin converting enzyme

didn't occur, but in one case. The patient with high Lp(a) (more than $180 \mathrm{mg} / \mathrm{dL}$ ) had dyspnea on exertion (fast walking) and needed coronarography. Subtotal stenosis of the right coronary artery was found out, and was exposed to stenting. In our opinion, it was caused by the extensive posttraumatic bruising of the lower limb in the context of inflammation. During this period according to the laboratory data the patient had high fibrinogenemia (6.5-7.4 g/L), high level of C-reactive protein 3.4-12.6 $\mathrm{mg} / \mathrm{dL}$, erythrocyte sedimentation rate (ESR) - 25-32 mm/min, Lp(a) 185-171 mg/dL, LDL - 2.5-2.7 mmol/L, atherogenic index - 1.9-2. The high level of CRP is responsible for atherosclerotic process progression and development of acute complications (even in the presence of normal levels of LDL).

As anticoagulation we used the heparin (15-30 U/kg/h). The level of circuit anticoagulation was estimated according to the activated clotting time, which was maintained within 180-200 s. The heparin supply was stopped before the last 10-15 min of the session.

We noted statistically significant dynamics of almost the studied indications after the procedures [Tables 3-6]. The patients of the 1st group had twofold decrease of total cholesterol and threefold decrease of LDL. The patients of the 2nd group had similar changes: threefold decrease of the total cholesterol and $68 \%$ decrease of LDL. Both types of lipid apheresis treatment proved to be effective for Lp(a)emia. We noted significant decrease (more than 65\%) of this atherogenic indication following these therapies [Tables 3 and 4]. Hematological parameters, ESR, hemoglobin concentration, fibrinogen, coagulation factors and activity of antithrombin had statistical significance immediately after the procedures [Tables 5 and 6].

After H.E.L.P.-apheresis HDL decreased by $29 \%$, and after cascade lipid-filtration - by $22 \%$. It was confirmed by the dynamics of apoprotein index ApoB100/apoA before and after the therapy (decrease by 33\% and almost by $60 \%$ while H.E.L.P.-apheresis and cascade lipid-filtration, respectively) and by the atherogenic index (38\% and 53\%, respectively) [Tables 3 and 4 ]. Significant changes were also found in the decrease of total protein and albumin levels following both the techniques. The total level of protein decreased by $24 \%$ and albumin - by $22 \%$ during H.E.L.P.-apheresis, and by $22 \%$ and $14 \%$, respectively, during cascade lipid- 
Table 3. Changes of laboratory data in the H.E.L.P.-apheresis group

\begin{tabular}{llll}
\hline Indices & Before procedures & After procedures & P value \\
\hline $\mathrm{Lp}(\mathrm{a}), \mathrm{mg} / \mathrm{dL}$ & $151.5(80.8-185)$ & $47.6(33-68.6)$ & 0.001 \\
Total cholesterol, mmol/L & $5.0(4.6-5.5)$ & $2.38(2.2-2.7)$ & 0.001 \\
Triglyceride, mmol/L & $1.5(1.1-1.9)$ & $0.9(0.5-1.2)$ & 0.001 \\
$\mathrm{LDL}, \mathrm{mmol} / \mathrm{L}$ & $2.9(2.6-3.2)$ & $1.0(0.9-1.3)$ & 0.001 \\
$\mathrm{HDL}, \mathrm{mmol} / \mathrm{L}$ & $1.28(1.0-1.5)$ & $0.91(0.7-1.1)$ & 0.001 \\
Atherogenic index & $2.9(2.3-4.2)$ & $1.8(1.3-2.8)$ & 0.001 \\
ApoA, mg/dL & $142(116-151)$ & $93(78-114)$ & 0.001 \\
ApoB100, mg/dL & $89(81-99)$ & $41(32-49)$ & 0.001 \\
Index ApoB100/ApoA & $0.7(0.6-0.8)$ & $0.47(0.3-0.6)$ & 0.001 \\
C-RP, mg/dL & $0.13(0.9-0.3)$ & $0.06(0.04-0.4)$ & 0.001 \\
Total protein, g/L & $66(62-69)$ & $50(46-53)$ & 0.001 \\
Albumin, g/L & $41(39-43)$ & $32(29-34)$ & 0.001 \\
\hline
\end{tabular}

LDL: low density lipoprotein; HDL: high density lipoprotein; C-RP: C-reactive protein

Table 4. Changes of laboratory data in the lipid-filtration group

\begin{tabular}{llll}
\hline Indices & Before procedures & After procedures & P value \\
\hline $\mathrm{Lp}(\mathrm{a}), \mathrm{mg} / \mathrm{dL}$ & $124(93-169)$ & $42.7(32.4-54.2)$ & 0.001 \\
Total cholesterol, mmol/L & $5.7(4.5-7.4)$ & $1.9(1.7-2.8)$ & 0.001 \\
Triglyceride, mmol/L & $2.2(1.7-2.6)$ & $0.7(0.5-0.8)$ & 0.001 \\
$\mathrm{LDL}, \mathrm{mmol} / \mathrm{L}$ & $3.8(2.5-5.7)$ & $1.2(0.8-2.1)$ & 0.001 \\
$\mathrm{HDL}, \mathrm{mmol} / \mathrm{L}$ & $0.9(0.9-1.0)$ & $0.7(0.6-0.8)$ & 0.001 \\
Atherogenic index & $4.5(3.8-6.9)$ & $2.1(1.5-3.5)$ & 0.001 \\
ApoA, mg/dL & $119(105-140)$ & $95(83-107)$ & 0.001 \\
ApoB100, mg/dL & $111.5(97.75-147.75)$ & $33(21.75-53)$ & 0.001 \\
Index ApoB100/ApoA & $0.8(0.75-1.28)$ & $0.34(0.2-0.65)$ & 0.001 \\
C-RP, mg/dL & $0.1(0.7-0.18)$ & $0.06(0.04-0.1)$ & 0.001 \\
Total protein, g/L & $70(67-72)$ & $55(52-57)$ & 0.001 \\
Albumin, g/L & $43(42-46)$ & $37(35-38)$ & 0.001 \\
\hline
\end{tabular}

LDL: Iow density lipoprotein; HDL: high density lipoprotein; C-RP: C-reactive protein

filtration. However, these changes were within the physiological intervals and didn't influence the clinical state of patients.

\section{DISCUSSION}

Our study presented 2 techniques of selective lipid apheresis for corrected lipid metabolism disorders in the high-risk patients with cardiovascular diseases. This group of patients needed more aggressive lipidlowering therapy with selective methods of lipid apheresis as the conventional therapy was insufficient and the level of Lp(a) was high. In this regard, we adhered to the clinical guidelines of MH of RF for treatment of Familial hypercholesterolemia, to the recommendations of associations for atherosclerosis treatment and recommendations of apheresis societies ${ }^{[1,31-34]}$. According to them, the program lipid apheresis is recommended for the patients with cardiovascular diseases due to atherosclerosis with hypercholesterolemia combined with high levels of $\mathrm{Lp}(\mathrm{a})$ (more than $60 \mathrm{mg} / \mathrm{dL}$ ).

Lipid apheresis therapies (regardless of the type of technique) are mainly aimed at dyslipidemia correction, atherogenic lipids elimination with preservation in antiatherogenic fractions circulation.

The decrease of lipid levels [LDL, Lp(a)] was statistically significant in both groups, and our results correlate with other studies. According to a number of other trials, decrease of atherogenic lipoproteins levels during the treatment is approximately within $60 \%-80 \%{ }^{[35,36]}$. Selective elimination of a great amount of lipid substances modifies the ratio of their fractions expectedly during the treatment. Although we 
Table 5. Changes of hematological and hemostatic parameters in the H.E.L.P.-apheresis group

\begin{tabular}{llcc}
\hline Indices & Before procedures & After procedures & $\boldsymbol{P}$ value \\
\hline Hemoglobin, $\mathrm{g} / \mathrm{L}$ & $131(128-137)$ & $116(112-127)$ & 0.001 \\
Hematocrit, \% & $39(38-42)$ & $35(34-38)$ & 0.001 \\
Platelets, $10^{9} / \mathrm{L}$ & $189(172-218)$ & $164(149-178)$ & 0.001 \\
WBC, $10^{9} / \mathrm{L}$ & $5.9(4.8-8.4)$ & $5.6(4.3-7.1)$ & 0.002 \\
ESR, mm/h & $15(12-20)$ & $3(2-4)$ & 0.001 \\
Fibrinogen, g/L & $4.5(4.2-5.2)$ & $1.92(1.57-2.31)$ & 0.001 \\
International Normalized Ratio INR & $1.02(0.97-1.12)$ & $1.53(1.33-1.76)$ & 0.001 \\
Antithrombin, \% & $114(104-118)$ & $78(72-79)$ & 0.001 \\
\hline
\end{tabular}

WBC: white blood cells; ESR: erythrocyte sedimentation rate; INR: International Normalised Ratio

Table 6. Changes of hematological and hemostatic parameters in the lipid-filtration group

\begin{tabular}{lllr}
\hline Indices & Before procedures & After procedures & P value \\
\hline Hemoglobin, g/L & $148(145-153)$ & $138(134-144)$ & 0.001 \\
Hematocrit, \% & $45(43-46)$ & $41(39-43)$ & 0.001 \\
Platelets, $10^{9} / \mathrm{L}$ & $209(199-221)$ & $184(167-202)$ & 0.001 \\
WBC, $10^{9} / \mathrm{L}$ & $8.4(7.4-9.3)$ & $10.2(9.7-10.3)$ & 0.002 \\
ESR, mm/h & $5(4-6)$ & $2(2-3)$ & 0.012 \\
Fibrinogen, g/L & $3.9(3.7-4.0)$ & $2.0(1.8-2.2)$ & 0.001 \\
INR & $1.00(0.93-1.05)$ & $1.26(1.17-1.37)$ & 0.001 \\
Antithrombin, \% & $99(95-109)$ & $83(73-94)$ & 0.043 \\
\hline
\end{tabular}

WBC: white blood cells; ESR: erythrocyte sedimentation rate; INR: International Normalised Ratio

observed decrease of LDL level, we pointed out positive correlation changings of atherogenic (LDL) and antiatherogenic (HDL) lipid fractions. This was approved by the change of apoprotein index apo B100/apo A-I and by the dynamics of atherogenic index ${ }^{[15,30]}$.

One explanation for the beneficial effect on vascular endothelium (and as a consequence, decrease of acute cardiovascular events frequency) is shock pulse decrease of atherogenic lipoproteins after the treatment ${ }^{[2]}$. The solution of this problem is lipid apheresis ${ }^{[33-35]}$.

Some researchers observe that simultaneous decrease of prothrombotic factors and atherogenic lipoproteins during lipid apheresis also can favour endothelium dysfunction improvement, inhibiting the progression of atherosclerotic damage and stabilizing the existing plaque ${ }^{[21,37]}$.

It is known that the elimination of fibrinogen (more than 60\%) and large-molecular substances according to the lipid apheresis techniques affects the blood and plasma viscosity, rheological characteristics and aggregation properties of cells (erythrocytes, platelets) ${ }^{[37,38]}$. Terai et al ${ }^{[39]}$ (2010) noted that changes of retina vessels' diameter are connected with systemic effect of LDL-apheresis, making basis for ocular perfusion improvement in the patients with hypercholesterolemia. In our study, positive feedback from the patients about subjective state improvement, particularly, increase of tolerance to the exertion, no drowsiness, productivity improvement, no dizziness, decrease of heart attacks was explained by objective findings, concerning decrease of large lipid molecular and fibrinogen levels, and as a consequence rheological blood characteristics improvement and microcirculation.

It should be noted a number of important pleiotropic and non-lipid, anti-inflammatory and rheological effects during the selective lipid apheresis ${ }^{[37,40-42]}$. Hibino et al. ${ }^{[43]}$ (2009) demonstrated anti-inflammatory and homeostasis-correcting effects of cascade rheofiltration. Hovland et al. ${ }^{[44]}$ (2010) studied the influence of different lipid apheresis therapies (DALI-hemoperfusion, plasma sorption LA-15 and cascade rheofiltration 
EC-50W) on hematological and rheological indications (hemoglobin, leukocytes, platelets, fibrinogen, thrombin-antithrombin complex, PAI-1, homocysteine) in the patients with familial hypercholesterolemia. It was shown, that regardless of the technology used apheresis therapy hematological and hemostatic parameters are affected differently, but still remain within the physiological intervals ${ }^{[4]]}$. This was also proved by our observations, as we didn't note cases with bleedings or thrombosis.

Probably, changes in hematological parameters, decrease of fibrinogen, coagulation factors and antithrombin levels can be also partially associated with some moderate dilution. Taking into account differences of treatment techniques at the stage of the extracorporeal circuit volume return, we noted more expressed changes of these indications immediately after H.E.L.P.-apheresis. The explanation is that approximately, 1.2-1.5 $\mathrm{L}$ of saline solution is necessary for returning maximum blood components from the circuit after H.E.L.P.-apheresis. On the other hand, decrease of fibrinogen concentration, INR and antithrombin level can be associated with consumption as a result of procoagulant activation of the blood in contact with the artificial circuit surface. Procoagulant activity is less advanced during cascade lipid-filtration.

Decrease of ESR is associated with reduction of lipid and fibrinogen concentration. The wide variation of ESR in the context of H.E.L.P.-apheresis can be associated with higher residual activity of heparin in the blood of the patient, the indirect evidence of which is elevated ESR.

The sets for measure the level of prothrombin time (INR) (HemosIL, RecombiPlastin 2G, ACL-TOP) include calcium chloride polybrene, which has the capacity to inhibit not more than $1 \mathrm{U} / \mathrm{mL}$ dose of heparin. For further studies we plan to estimate the level of heparin anti-Xa activity at different treatment stages. Multidirectional changes of the WBC amount are more likely to be associated with the small randomization and with individual body reactivity of the patients. This reaction is a physiological response to the procedure. Statistically significant changes of hematological parameters after procedures were within or on the border of reference intervals. Taking into account the slight dynamics differences of the analytes measured between the sessions, the treatment is recommended to be individually choice to each patient's condition ${ }^{[38,45]}$.

Lipid apheresis sessions frequency depends on the response to the therapy and lipidemia level (LDL, Lp(a)). The decreased level of lipids begins to increase gradually after the apheresis treatment. The "growth" degree is defined by catabolism rate and eliminated particles volume, as well as synthesis rate of these molecules. Given the cholesterol synthesis pool (10-14 days), a question occurs, whether it is necessary to perform program extracorporeal therapies, i.e., repeated sessions once per 2-3 weeks for a long period of time ${ }^{[32,46]}$. To complete one of the tasks in our study - provide gradual decrease of atherogenic cholesterol baseline to the target level - the sessions were performed once per 3-4 weeks along with pharmacological lipid-lowering therapies and diets. Though the researchers mainly point out the advisable interval of 2 weeks between the sessions, a number of authors show 3-4 weeks interval efficiency, and it correlates with our findings ${ }^{[25,30,37]}$.

The lipid apheresis therapy was safe and effective. In general, patients had a high appreciation, the sessions proved to be safe and well-tolerated. Types and rates of side effects of lipid apheresis treatment are described by different authors and in the registry of World Apheresis Association ${ }^{[47-50]}$. Heigl et al ${ }^{[51]}$ (2015) studied safety during 6 years and noted good tolerance to different techniques of lipid apheresis. As a whole, according to the results of Heigl et al..$^{[51]}$ (2015), side effects were not more than $1.1 \%$ (vascular issues, technical issues). The study of Borberg et al. ${ }^{[48]}$ (2009) on lipid apheresis safety evaluation with more than 2,500,000 sessions registered in the world, confirm the general assessment of a small number of slight and moderately expressed side effects - 3.3\%. The issues, described by him, are problems of vascular access, hypotension at the connection stage, allergic reactions, bruising after puncture and technical issues.

Even in the ' 90 s Geiss et al. ${ }^{[52]}$ found out, that membrane cascade filtration is an effective method for decrease of elevated concentrations of atherogenic lipoproteins. And the concomitant loss of other macromolecules 
improves blood rheology temporarily, but careful monitoring of proteins and immunoglobulin levels changes is needed to provide the safety of the treatment. Development of new membranes with different cut-off points (permeability) and improvement of equipment will enable safe and effective double or triple filtration in the near future. These hollow fibers will be manufactured with pores of certain size. They will allow performing selective and quite accurate filtration. The main clinical benefit will be the possibility to preserve important physiological proteins, coagulation factors, hormones and enzymes. Thus, cascade rheofiltration methodology can be attributed to the selective lipid apheresis sessions group.

As a result of our study and based on the data of the other researchers, we can notice about successful application of therapeutic apheresis in the complex treatment of patients with multifocal atherosclerosis and its complications. This type of treatment is safe and highly effective for dyslipidemia corrections, elimination of atherogenic lipoproteins, stabilization of atherosclerotic process and endothelium state, hemostasis correction and immunological indications, metabolism disorders, etc.

Extracorporeal therapy for lipid metabolism disorders should be tailored to the individual patient condition, depending on clinical and laboratory parameters of the patient (type of dyslipidemia, hemostasis state, comorbidities). Besides, the priority attention while choosing the apheresis method is given to staff expertise and technical capabilities of the clinic.

Lipid apheresis techniques should be applied for primary and secondary prevention of atherosclerosis events in the context of severe disorders of lipid metabolism, refractory and conventional therapy (diet, medications) to improve the treatment prognosis and the quality of life of the high-risk group of patients. Blood purification techniques are known to have high cost, and not all the medical centers are able to apply them for complex therapy of cardiovascular diseases. But this tendency is evolving and penetrating the clinical practice.

\section{DECLARATIONS}

\section{Author's contributions}

Contributed to the conception, design and methodology of the study, analysed the results and wrote the manuscript: Yaroustovsky M, Abramyan M

Collected samples and provided clinical data: Rogalskaya E, Komardina E

Read and approved the final manuscript: All authors

\section{Availability of data and materials}

The relevant data in this study can be obtained from corresponding author.

\section{Financial support and sponsorship}

None.

\section{Conflicts of interest}

All authors declared that there are no conflicts of interest.

\section{Ethical approval and consent to participate}

The related study was approved by the Local Ethics Committee of the A.N.Bakulev NMRCCVS. Patients included in the study signed an informed consent for extracorporeal therapy.

\section{Consent for publication}

Not applicable. 


\section{Copyright}

(c) The Author(s) 2019.

\section{REFERENCES}

1. Sokolov AA, Alexandrova OY, Kashtalap VV, Barbarash OL, Yezhov MV. Guidelines on the medical care organization to the patients with hereditary atherogenic lipid disorders in the Regions of Russia (Joint project of the national society for the research on atherosclerosis and non-profit partnership "The national council of experts on rare diseases"). Bulletin Contempor Clin Med 2017;10:83-8. (in Russia).

2. Townsend N, Nichols M, Scarborough P, Rayner M. Cardiovascular disease in Europe epidemiological update 2015. Eur Heart J 2015;36:2696-705.

3. Bergheanu SC, Bodde MC, Jukema JW. Pathophysiology and treatment of atherosclerosis: current view and future perspective on lipoprotein modification treatment. Neth Heart J 2017;25:231-42.

4. Klose G, Laufs U, Marz W, Windler E. Familial hypercholesterolemia: developments in diagnosis and treatment. Dtsch Arztebl Int 2014;111:523-9.

5. Orsó E, Ahrens N, Kilalić D, Schmitz G. Familial hypercholesterolemia and lipoprotein(a) hyperlipidemia as independent and combined cardiovascular risk factors. Atheroscler Suppl 2009;10:74-8.

6. Sobenin IA, Galitsyna EV, Grechko AV, Orekhov AN. Small dense and desialylated low density lipoprotein in diabetic patients. Vessel Plus 2017;1:29-37.

7. Daniels SR, Greer FR, Committee on Nutrition. Lipid screening and cardiovascular health in childhood. Pediatrics 2008;122:198-208.

8. Hohenstein B, Julius U, Lansberg P, Jaeger B, Mellwig KP, et al. Rationale and design of MultiSELECt: a European multicenter study on the effect of Lipoprotein(a) elimination by lipoprotein apheresis on cardiovascular outcomes. Atheroscler Suppl 2017;30:180-6.

9. Bos S, Yayha R, van Lennep JE. Latest developments in the treatment of lipoprotein(a). Curr Opin Lipidol 2014;25:452-60.

10. Lamon-Fava S, Diffenderfer MR, Marcovina SM. Lipoprotein(a) metabolism. Curr Opin Lipidol 2014;25:189-93.

11. Pokrovsky SN, Afanasieva OI, Safarova MS, Balakhonova TV, Matchin YG, et al. Specific Lp(a) apheresis: a tool to prove lipoprotein(a) atherogenicity. Atheroscler Suppl 2017;30:166-73.

12. Stefanutti C, Thompson GR. Lipoprotein apheresis in the management of familial hypercholesterolaemia: historical perspective and recent advances. Curr Atheroscler Rep 2015;17:465.

13. Abramyan MV. Possibilities of LDL-apheresis in the complex treatment of atherosclerosis. Creative Cardiology 2007;1-2:208-19. (in Russia)

14. Makino H, Tamanaha T, Harada-Shiba M. LDL apheresis in Japan. Transfus Apher Sci 2017;56:677-81.

15. Stefanutti C, Julius U, Watts GF, Harada-Shiba M, Cossu M, et al. Toward an international consensus-integrating lipoprotein apheresis and new lipid-lowering drugs. J Clin Lipidol 2017;11:858-71.

16. Waldmann E, Parhofer KG. Lipoprotein apheresis to treat elevated lipoprotein (a). J Lipid Res 2016;57:1751-7.

17. de Gennes JL, Touraine R, Maunand B, Truffert J, Laudat P. Homozygous cutaneo-tendinous forms of hypercholesteremic xanthomatosis in an exemplary familial case. Trial of plasmapheresis and heroic treatment. Bull Mem Soc Med Hop Paris 1967;118:1377-402.

18. Thompson GR, Lowenthal R, Myant NB. Plasma exchange in the management of homozygous familial hypercholesterolaemia. Lancet $1975 ; 1: 1208-11$.

19. Thompson GR, Myant NB, Kilpatrick D, Oakley CM, Raphael MJ, et al. Assessment of longterm plasma exchange for familial hypercholesterolaaemia. Br Heart J 1980;43:680-8.

20. Briel M, Ferreira-Gonzalez I, You JJ, Karanicolas PJ, Akl EA, et al. Association between change in high density lipoprotein cholesterol and cardiovascular disease morbidity and mortality: systematic review and meta-regression analysis. BMJ 2009;338:b92.

21. Nenseter MS, Bogsrud MP, Græsdal A, Narverud I, Halvorsen B, et al. LDL-apheresis affects markers of endothelial function in patients with homozygous familial hypercholesterolemia. Thromb Res 2012;130:823-5.

22. Derfler K, Steiner S, Sinzinger H. Lipoprotein-apheresis: Austrian consensus on indication and performance of treatment. Wien Klin Wochenschr 2015;127:655-63.

23. Julius U. History of lipidology and lipoprotein apheresis. Atheroscler Suppl 2017;30:1-8.

24. Winters JL. Lipid apheresis, indications, and principles. J Clin Apher 2011;26:269-75.

25. Julius U. Current role of lipoprotein apheresis in the treatment of high-risk patients. J Cardiovasc Dev Dis 2018;5:27.

26. Kozik-Jaromin J, Röseler E, Heigl F, Spitthöver R, Ringel J, et al. Safety aspects of lipidapheresis using DALI and MONET multicenter observational study. Atheroscler Suppl 2017;30:225-31.

27. Temizhan A, Cetin EH, Cetin MS, Tak BT. Comparison of two lipid apheresis systems in patients with homozygous familial hypercholesterolemia: a single center 3-year experience. JACC 2018;71:1780.

28. Klingel R, Mausfeld P, Fassbender C, Goehlen B. Lipidfiltration-safe and effective methodology to perform lipid-apheresis. Transfus Apher Sci 2004;30:245-54.

29. van Buuren F, Kreickmann S, Horstkotte D, Kottmann T, Mellwig KP. HELP apheresis in hypercholesterolemia and cardiovascular disease: efficacy and adverse events after 8,500 procedures. Clin Res Cardiol Suppl 2012;7:24-30. 
30. Yarustovskiy MB, Abramyan MV, Pliysch MG, Samsonova NN, Nazarova EI, et al. New medical technologies in cardiovascular surgery. Treatment of atherosclerosis and its complications using H.E.L.P.-apheresis method. Creative Cardiology 2009;2:98-116. (in Russia)

31. Page MM, Bell DA, Hooper AJ, Watts GF, Burnett JR. Lipoprotein apheresis and new therapies for severe familial hypercholesterolemia in adults and children. Best Pract Res Clin Endocrinol Metab 2014;28:387-403.

32. Schwartz J, Padmanabhan A, Aqui N, Balogun RA, Connelly-Smith L, et al. Guidelines on the use of therapeutic apheresis in clinical practice-evidence-based approach from the writing committee of the American society for apheresis: the seventh special issue. J Clin Apher 2016;31:149-62.

33. Thompson GR, Catapano A, Saheb S, Atassi-Dumont M, Barbir M, et al. Severe hypercholesterolaemia: therapeutic goals and eligibility criteria for LDL apheresis in Europe. Curr Opin Lipidol 2010;21:492-8.

34. Wang A, Richhariya A, Gandra ShR, Calimlim B, Kim L, et al. Systematic review of low-density lipoprotein cholesterol apheresis for the treatment of familial hypercholesterolemia. J Am Heart Assoc 2016;5:e003294.

35. Hovland A, Marcovina S, Hardersen R, Enebakk T, Mollnes TE, et al. Three different LDL apheresis columns efficiently and equally reduce lipoprotein(a) concentrations in patients with familial hypercholesterolemia and small apolipoprotein(a) particles. J Clin Apher 2012;46:73-6.

36. Marcovina SM, Koschinsky ML, Albers JJ, Skarlatos S. Report of the national heart, lung, and blood institute workshop on lipoprotein(a) and cardiovascular disease: recent advances and future directions. Clin Chem 2003;49:1785-96.

37. Wang Y, Blessing F, Walli AK, Uberfuhr P, Fraunberger P, et al. Effects of heparin-mediated extracorporeal low-density lipoprotein precipitation beyond lowering proatherogenic lipoproteins - reduction of circulating proinflammatory and procoagulatory markers. Atherosclerosis 2004;175:145-50.

38. Moriarty PM, Minchew HM, Oktona DC. Treating lipoprotein(a)- hyperproteinemia and progressive cardiovascular disease with lipidapheresis in North America. JACC 2018;71:1784.

39. Terai N, Julius U, Haustein M, Spoerl E, Pillunat LE. The effect of low-density lipoprotein apheresis on ocular microcirculation in patients with hypercholesterolemia: a pilot study. Br J Ophthalmol 2011;95:401-4.

40. Sinzinger H, Steiner S, Derfler K. Pleiotropic effects of regular lipoprotein-apheresis. Atheroscler Suppl 2017;30:122-27.

41. Hovland A, Lappegård KT, Mollnes TE. LDL apheresis and inflammation - implications for atherosclerosis. Scand J Immunol 2012;76:229-36.

42. Kopprasch S, Bornstein SR, Bergmann S, Graessler J, Julius U. Long-term therapeutic efficacy of lipoprotein apheresis on circulating oxidative stress parameters - a comparison of two different apheresis techniques. Atheroscler Suppl 2015;18:80-4.

43. Hibino S, Seok YK, Tsuda H, Yonei Y. Effect of double filtration plasmapheresis (DFPP) in male patients with borderline hyper-LDLcholesterolemia: lipid removal and inflammation suppreesion. Anti-Aging Medicine 2009;6:32-40.

44. Hovland A, Hardersen R, Nielsen EW, Mollnes TE, Lappegård KT. Hematologic and hemostatic changes induced by different columns during LDL apheresis. J Clin Apher 2010;25:294-300.

45. Rogova LN, Gubanova EI, Pankova GV, Shepeleva TI. Pathogenetic substantiation of the interpretation of the results of hematological analysis of blood. Bulletin of Medical Internet Conferences 2016;6:1568-72. (in Russia)

46. Thompson GR, Barbir M, Davies D, Dobral P, Gesinde M, et al. Efficacy criteria and cholesterol targets for LDL apheresis. Atherosclerosis 2010;208:317-21.

47. Blaha M, Ptak J, Cap J, Ceeová V, Mašín V, et al. WAA apheresis registry in the Czech Republic: two centers experience. Transfus Apher Sci 2009;41:27-31.

48. Borberg H. 26 years of LDL - apheresis: a review of experience. Transfus Apher Sci 2009;41:49-59.

49. Henriksson MM, Newman E, Witt V, Derfler K, Leitner G, et al. Adverse events in apheresis: an update of the WAA registry data. Transfus Apher Sci 2016;54:2-15.

50. Stegmayr B, Mörtzell Henriksson M, Newman E, Witt V, Derfler K, et al. Distribution of indications and procedures within the framework of centers participating in the WAA apheresis registry. Transfus Apher Sci 2017;56:71-4.

51. Heigl F, Hettich R, Lotz N, Reeg H, Pflederer T, et al. Efficacy, safety, and tolerability of long-term lipoprotein apheresis in patients with LDL- or Lp(a) hyperlipoproteinemia: Findings gathered from more than 36,000 treatments at one center in Germany. Atheroscler Suppl 2015;18:154-62.

52. Geiss HC, Parhaofer KG, Donner MG, Schwandt P. Low-density lipoprotein apheresis by membrane differential filtration. The Scientific World Journal (cascade filtration). Ther Apher Dial 1993;3:199-202. 